\title{
REVIEWS
}

\section{Detection of Chromosomal Abnormalities with Different In Situ Hybridisation Techniques - the Usefulness in the Qualification of Cancer Patients for Molecularly-Targeted Therapies}

${ }^{1}$ Department of Pneumonology, Oncology and Allergology, Medical University of Lublin Postgraduate School of Molecular Medicine, Medical University of Warsaw, Poland

2 Department of Pneumonology, Oncology and Allergology, Medical University of Lublin, Poland

A - research concept and design; $\mathbf{B}$ - collection and/or assembly of data; $\mathbf{C}$ - data analysis and interpretation;

$\mathbf{D}$ - writing the article; $\mathbf{E}$ - critical revision of the article; $\mathbf{F}$ - final approval of article; $\mathbf{G}$ - other

\begin{abstract}
Proper qualification of patients with cancer for an effective treatment regiment is essential to rationalize therapy benefit and costs. The early detection of genetic disorders that are responsible for the stimulation of uncontrolled cancer cells proliferation makes it possible to select a group of patients with a high probability of response to molecularly-targeted therapy. Data has shown that careful analysis of genes mutation using different PCR and sequencing techniques or chromosomal aberrations using in situ hybridization (ISH) techniques have a predictive value for drug targeted therapy. Overexpression of receptors and gene amplification has been reported in various cancers. Their detection is still a considerable challenge, which is connected with the unsatisfactory quality of DNA and low mutated cells percentage compared to cells with no genetic abnormalities in tested material. Different techniques of standardization were performed to prevent false negative results and to increase the sensitivity of qualitative and quantitative evaluation of chromosomal abnormalities. Immunohistochemistry (IHC) technique is useful in the screening of receptor expression in paraffin-embedded tissue samples in different malignant diseases. Whereas ISH techniques, especially fluorescence in situ hybridization (FISH), are now considered the diagnostic gold standard method in detection chromosomal aberrations. Moreover, molecular biology techniques, which are using molecular probes and real-time PCR and quantitative PCR techniques, were also applied for the detection of chromosomal changes. In order to identify the best genetic marker for treatment regiment, it is important to compare results of different studies, which are evaluating the sensitivity of diagnostic techniques and treatment response after a suitable selection factors based on genetic aberrations profile (Adv Clin Exp Med 2015, 24, 4, 715-723).
\end{abstract}

Key words: immunohistochemistry, genetic driver abnormalities, in situ hybridization, molecularly-targeted therapies.

Cancer diseases are one of the leading causes of death worldwide. According to the geographical location, epidemiological observations show various cancer morbidity and mortality, which are caused by different risk factors and differences in diagnostic or therapeutic procedures. Late diagnosis and limited access to appropriate therapy, including molecularly-targeted therapy, significantly reduces a cancer patient's chances of survival [1-3].
Molecular studies reported that genetic and epigenetic disorders cause neoplasm transformations with rapid proliferation, differentiation and inhibition of cells apoptosis. These processes combined with uncontrolled angiogenesis lead to clonal tumor growth. Until now, it has been reported that only some mutations in DNA are able to stimulate uncontrolled expansion of cancer cells. Currently, also chromosomal aberrations (aneuploidy 
and deletion/inversion/translocation) are considered as new therapeutic targets that lead to the development of molecularly-targeted therapies. In recent years, it was proven that treatment selection based on the individual patient's genetic profile brings spectacular benefits. Currently, many sensitive and specific laboratory tests for genes and chromosomal abnormalities as well as gene expression provide the ability to detect genetic disorders even in low-cellularity materials [2-5].

All available methods that are used to search for chromosome aberrations or receptor overexpression present the same advantages and disadvantages (Table 1). Among others, immunohistochemical staining (IHC) is used for the evaluation of protein expression in gastric or breast cancers as well as in metastatic colorectal cancer, but in other diseases there are no standardized IHC protocols (e.g. in lung cancer patients). However, the decision to start molecularly-targeted therapy cannot be undertaken if the IHC results are uncertain. $\mathrm{Pa}$ tients with metastatic colorectal cancer may benefit from anti-EGFR treatment even if cancer cells do not express EGFR protein in the IHC method. Moreover, this technique was not used in clinical trials to qualify lung cancer patients for molecularly-targeted therapies, so there is little data about the efficiency of this treatment in lung cancer patients with an expression of abnormal proteins (EML4-ALK and therapy with ALK inhibitors) $[6-11]$.

In situ hybridization (ISH) is a technique that allows the precise localization of a specific segment of nucleic acid on histological section. The underlying basis of ISH is that nucleic acids, if preserved adequately on a histological specimen, can be detected through the application of complementary probes. Visualization of the probes allows us to locate DNA or RNA sequences in a heterogeneous cell population, including tissue samples or cellblock samples. In chromogenic in situ hybridization (CISH) probes are labeled with an antigenic moiety and detected via antibodies conjugated to an enzyme, typically horseradish peroxidase (HRP) or alkaline phosphatase (AP), which catalyzes reactions of chromogenic substrates and can be detected under a standard bright-field microscope. An increasingly popular variation of in situ hybridization techniques employs metallographic detection. Here, the hybridization probe is linked to an enzyme that elicits the neutralization and deposition of metal - most commonly silver - out of a solution and onto the probe target site (silver-enhanced in situ hybridization, SISH). While the resulting stain has only a single color; black, it is generally dense, fine-grained and absolutely stable. Fluorescence in situ hybridization (FISH) uses fluorescent probes that bind to only those parts of the chromosome with which they show a complete sequence of complementarities. Fluorescence microscopy can be used to find out where the fluorescent probe is bound to the chromosomes and probes labeled with different fluorochromes could be used in one assay $[8,11,12]$.

Currently, fluorescence in situ hybridization (FISH) is considered a gold standard in the diagnostic process of genetic aberrations in various cancers (lung cancer - $A L K$ gene rearrangements, breast cancer and gastric cancer - HER2 gene amplification in the case of unreliable results of IHC examination). Although 100\% correlation between the negative results of FISH and IHC tests has been demonstrated, most guidelines recommend the confirmation of IHC positive results by the FISH technique. CISH and dual-color in situ hybridization (DISH) can be used as an alternative to the FISH technique. However, it is necessary to compare the results of different analyses in order to properly select the appropriate method for determination and classification of patients for effective therapy [6-11].

The technique based on reverse transcription (polymerase chain reaction - RT-PCR) enables detection of a very low copy number of RNA molecules and makes it possible to avoid discrepancies connected with visual evaluation and interpretation of IHC or FISH results. Unfortunately, insufficient sensitivity of RT-PCR, arising from the low quality of genetic material and low proportion of mutant cells isolated from paraffin-embedded tissue samples, significantly reduces the usefulness of this method for determining genomic or receptor aberrations. In addition, using several molecular probes, RT-PCR allows the detection of only well-known abnormalities. For this reason, most authors use proven FISH and IHC techniques to qualify the patients for appropriate therapies [11-17].

\section{The Significance of the FISH Technique in Qualification of Non-Small Cell Lung Cancer Patients for Molecularly- -Targeted Therapy}

Genetic research identified many driver mutations which are significant for the qualification of non-small cell lung cancer (NSCLC) patients for 
Table 1. Summary of the techniques advantages and disadvantages in determination of chromosomal aberrations and gene expression [12]

\begin{tabular}{|l|l|l|l|}
\hline & FISH & IHC & RT-PCR \\
\hline Advantages & $\begin{array}{l}\text { availability (and reliability) of } \\
\text { validated kit with standard pro- } \\
\text { cedures used in clinical trials }\end{array}$ & user and costs friendly & $\begin{array}{l}\text { high specificity, not require avail- } \\
\text { ability of homogenous nuclei or } \\
\text { cells }\end{array}$ \\
\hline Disadvantages & $\begin{array}{l}\text { technically challenging and } \\
\text { costly, access to non-damaged } \\
\text { material, experience of the staff, } \\
\text { laboratory equipped with fluo- } \\
\text { rescent microscope }\end{array}$ & $\begin{array}{l}\text { necessity access to meaningful } \\
\text { tissue material, access to non- } \\
\text { damaged material, unreliabil- } \\
\text { ity of borderline results }\end{array}$ & $\begin{array}{l}\text { high quality of mRNA obtained } \\
\text { from frozen samples and FFPE is } \\
\text { required, only known variants can } \\
\text { be identified, laboratory equipped } \\
\text { with real-time PCR instrument }\end{array}$ \\
\hline
\end{tabular}

In terms of insufficient sensitivity of RT-PCR in low quality of DNA and RNA isolated from paraffin-embedded tissue samples, the FISH and the IHC techniques are considered to be proper tests to diagnose chromosomal and genes aberration. However, the FISH technique is considered a gold standard in the diagnostic process and most guidelines recommend confirmation of all IHC positive results by the FISH technique.

molecularly-targeted therapies. There are many reports that activation of somatic epidermal growth factor receptor $(E G F R)$ gene mutations lead to the stimulation of oncogenic pathways, which are dependent on tyrosine kinase phosphorylation. Previous studies indicated that EGFR tyrosine kinase inhibitors (EGFR TKIs) offer patients with EGFR gene abnormalities significant benefits as compared to standard chemotherapy $[2,15,18]$.

Early observations reported that increased EGFR gene copy number (GCN) was strongly correlated with the prolongation of both progressionfree survival (PFS) and overall survival (OS) after EGFR TKIs treatment. These results suggested that EGFR GCN may be a good indicator of treatment sensitivity. Until now, it has not yet been clarified whether the high EGFR GCN may be the effective targeted therapy predictor $[18,19]$.

Wang et al. retrospectively evaluated the EGFR GCN and EGFR gene mutations status in 499 NSCLC patients treated with EGFR TKIs. Based on the positive results of FISH assays, they observed the presence of EGFR gene amplification (FISH+) in $45 \%$ of patients, whereas $50.5 \%$ of patients had activated EGFR gene mutations (Asian population). The data comparison showed that $64.7 \%$ of patients with EGFR gene mutations had also expressed EGFR gene amplification, while only $25.1 \%$ of wildtype EGFR gene patients showed FISH positive results. More therapy benefits, PFS of 12.9 months (vs. 7.9) and OS of 35.9 months (vs. 25.7), were observed in a group of double-positive patients (EGFR mutations and amplification). Nevertheless, the authors conclude that EGFR mutations are the most objective biomarker of response to EGFR TKIs therapy. Although, the sensitivity to the targeted treatment in patients with the EGFR gene amplification (FISH indicated) is often due to the coexistence with EGFR mutations in these patients [18].
Liang et al. retrospectively evaluated 133 NSCLC patients and reported the presence of activating EGFR gene mutations in $63.9 \%$ of the studied group. What is more, in $80.4 \%$ of patients the EGFR gene amplification and in 68\% EGFR protein overexpression determined by the IHC technique was detected. A summary of the results showed a significantly higher frequency of EGFR gene mutations in IHC positive patients (65/91). Moreover, the overexpression of the EGFR protein correlated with the EGFR gene amplification [19].

In the Scholl et al. study, 38 patients treated with EGFR TKIs (19 of them had EGFR gene mutation, 20 patients - FISH+ and 14 patients - IHC+) were qualified for the determination of which abnormalities in EGFR signaling pathway predict the probability of response to EGFR TKIs. Correlations of molecular results with therapeutic effects indicated that the status of EGFR gene mutations shows the best response rate to EGFR TKIs therapy. A beneficial treatment result was also observed in 8 wild-type EGFR gene patients (2 patients were FISH-positive and 6 patients IHC-positive). Furthermore, the analysis of the IHC results allowed showed some trends indicating that the EGFR overexpression (IHC+) may suggest a higher probability of disease stabilization, but these outcomes have not yet been confirmed in a larger study group [13].

Brugger et al., based on the observation of 889 patients (438 of them received erlotinib), also stated that positive EGFR gene mutations status had the best response rate to molecularly-targeted therapy. Although in a studied group, EGFR TKIs prolonged PFS both in patients with the EGFR overexpression and with EGFR gene amplification (without statistical significances). Only patients with EGFR gene activating mutations (11\% of treated group) had a significant PFS increase during the treatment [20]. 
In the Iressa Pan-Asia Study (IPASS) prolongation of PFS was observed in patients with EGFR gene amplification treated by gefitinib. Furthermore, it was indicated that $78 \%$ of FISH+ patients were simultaneously carriers of activating EGFR gene mutations and it was considered as a major cause of treatment efficiency. In order to confirm these suspicions, they demonstrated that the PFS was significantly shorter in FISH-positive patients with a wild-type EGFR gene. Based on the IPASS study, gefitinib had been approved for the first-line treatment of patients with EGFR gene mutation, regardless of the EGFR gene GCN. Likewise, the effectiveness of gefitinib in patients with EGFR GCN was also not proven in INTEREST trial $[17,21]$.

On the other hand, according to results of the BR.21 study erlotinib had been approved for the $2^{\text {nd }}$ and $3^{\text {rd }}$ lines treatment irrespectively of EGFR gene status. However, a higher response rate to erlotinib was observed among patients both with high EGFR GCN and EGFR gene mutations, but a significance was reported only for GCN $(\mathrm{p}=0.008)$. The EURTAC study demonstrated that the presence of EGFR gene mutations in only one predictive factor for the erlotinib in first-line therapy $[3,17,21]$.

Also, anaplastic lymphoma kinase $(A L K)$ gene fusion with echinoderm microtubule-associated protein-like 4 (EML4) gene, detected in 3\% to $7 \%$ of adenocarcinoma NSCLC patients (mostly young and non-smokers), leads to constitutive activation of MAP, PI3K and STAT oncogenic signalling pathways. According to previous data $A L K$ gene rearrangement detection in NSCLC patients is used in the qualification for molecularly-targeted therapy (crizotinib phase II/III clinical trials - PROFILE 1005 PROFILE 1007 PROFILE 1014). In Marchetti et al. $61 \%$ of patients with $A L K$ gene rearrangement had responded to molecularly-targeted agents and had reached PFS of 10 months. Moreover, 1- and 2-year-OS were at 74\% and 54\% level [2, 11-13].

Thus far, studies have not shown the usefulness of RT-PCR in ALK gene rearrangement diagnosis; therefore, FISH is the only technique recommended for this aberration determination. What is more, recommendations suggest that the IHC technique can be used as a screening method to reduce study costs, although some positive IHC results should be confirmed by the FISH technique. Kim et al. had compared the presence of ALK protein overexpression and $A L K$ gene rearrangement and they observed $92.4 \%$ concordance between the positive results of IHC and CISH analysis. Chen et al. had reported $A L K$ gene rearrangement in 64 patients (detected by RT-PCR); however, only
2 patients showed strong overexpression of ALK protein (IHC3+) and 46 of them showed ALK expression on $\mathrm{IHC1}+$. Zhang et al. had observed the concordance between positive results of RT-PCR, IHC and FISH analysis only in $15.3 \%$ (20/130) of screened patients. Furthermore, in this study the authors noticed $100 \%$ comparable of IHC and FISH results. $\mathrm{Wu}$ et al. had concluded that only IHC3-positive and FISH+ results are in some measure comparable to RT-PCR [11, 12, 22-26].

Rare ROS1 gene rearrangement, which is observed in $1.2-1.7 \%$ of NSCLC patients, in the near future can be a potential target for drugs with anti-ROS1 activity. Bergethon et al. had reported moderate inhibition of proliferation of tumor cell line (HCC78) by ALK kinase inhibitor (NVPTAE684). On the other hand, Davies et al. had observed a higher effectiveness of ROS1 receptor phosphorylation inhibition by a dual ALK and MET inhibitor (crizotinib). Moreover, they noticed $57 \%$ of tumor size reduction in ROS1-positive patients (determined by FISH analysis) after 2 cycles of treatment $[27,28]$.

\section{The Significance of HER2 Status in Breast Cancer Patients Qualifications for Molecularly-Targeted Therapies}

HER2 gene amplification and overexpression of HER2 have been reported in $20-50 \%$ of breast cancer patients. These genetic targets are considered as prognostic factors which are able to define the aggressiveness of the disease and the sensitivity to trastuzumab and lapatinib treatment. Gullo et al. had observed that HER2 gene amplification is higher in primary tumors rather than in metastases. Moreover, the presence of HER2 abnormalities is associated with the shortening of OS and has no effect on the advancement of disease at the time of diagnosis, advancement of tumor differentiation and expression of estrogen and progesterone receptors $[29,30]$.

IHC or FISH validated tests can be used to estimate HER2 receptor status. In the IHC technique, positive results are defined by $\mathrm{IHC} 3+$ whereas IHC2+ expression is referred as inconclusive and needs assessment of HER2 GCN in FISH. Only FISH results with exhibiting $>2$ ratio signals are defined as amplified and $<1.8$ as non-amplified. Borderline HER2 FISH results (1.8-2.0 ratio or 4-6 HER2 GCN) should be assessed using reverse transcriptase PCR methodology. Moreover, in the 
near future automated nuclei-sampling analysis can also be recommended to avoid uncertain results $[14,31]$.

Except trastuzumab, other HER2 inhibitors have been tested in clinical trials: pertuzumab, ado-trastuzumab emtansinse and lapatinib show effectiveness in breast cancer patients with amplification of HER2 gene or high expression of HER2 protein. The Clinical Evaluation of Pertuzum$\mathrm{ab}$ and Trastuzumab (CLEOPARA) research rated the effectiveness of petruzumab in a multidrug pattern combined with trastuzumab and docetaxel in FISH+ patients with breast cancer metastatic tumors. On the other hand, the EMILIA study evaluated the effectiveness of trastuzumab emtansine (T-DM1) antibody in second-line treatment after acquired resistance to trastuzumab and taxanes in primary breast cancer. The clinical trials results were presented in Table $2[32,33]$. In case of resistance or insensitivity to trastuzumab, pertuzumab is able to provide new possibilities for treating breast cancer patients. Cortes et al. had evaluated the efficacy of petruzumab monotherapy in 29 HER2-positive patients and compared this result with combined therapy (pertuzumab with trastuzumab). They found the prolongation of PFS by week 7.1 in patients treated with combined therapy. This effect could result from the mechanism of both drugs - they are bound by different epitopes in the HER2 receptor. For this reason they show complementary action with a more efficient blockade of the HER2 signaling pathways, which resulted in increasing antitumor activity $[10,32]$.

Lapatinib - tyrosine kinase inhibitor, which interrupts the HER2 and EGFR pathways, showed a rate of $12.4-25 \%$ clinical benefit in HER2-positive breast cancer patients pretreated with trastuzumab. On the other hand, the EGF100151 study estimated the effectiveness of lapatinib in combination with capecitabine in such a group of patients, prolonged median time to progression
(TTP) for 8.4 months. Moreover, improvement of the overall response rate $(22 \%)$ and clinical benefit rate $(27 \%)$, without increase in serious toxic effects was achieved [16, 34, 35].

Advanced clinical trials suggest that the FISH technique is the most useful in qualification of breast cancer patients for molecularly-targeted therapy. Horii et al. had obtained $98.5 \%$ concordance $(\mathrm{p}=0.005)$ between FISH and DISH results. The study also proved that the DISH technique, due to simultaneous observation of signals from HER2 receptor and chromosome 17, may be more useful in evaluation of HER2 gene status in the qualification of breast cancer patients for appropriate therapy [33].

Likewise Jacquemier et al. had demonstrated 98\% concordance between CISH and FISH results. Moreover, the authors observed 95\% compatibility between FISH and quantitative PCR (qPCR) results carried out in DNA isolated from paraffinembedded tissue samples. The outcomes are more promising than the results of analyses performed by RT-PCR that RNA is more sensitive to degradation during the paraffining process [29].

\section{The Significance of FISH Analysis in Qualification for Anti-HER2 Targeted Therapy in Gastric Cancer}

The HER2 gene disorders are detected not only in breast cancer patients, but also in $15-20 \%$ of gastric cancer patients. Luis et al. suggested that the IHC technique should be used as a screening test for HER2 status diagnosis, wherein patients with high expression of HER2 protein (IHC3+) are the major candidates for molecularly-targeted therapy. However, IHC2+ results must be confirmed by more sensitive in situ hybridization methods [34-37].

Table 2. Results summary of anti-HER2 clinical trials in HER2-positive patients

\begin{tabular}{|l|l|l|l|l|l|}
\hline Clinical trial & Treatment & $\begin{array}{l}\text { PFS } \\
{[\text { months }]}\end{array}$ & $\begin{array}{l}\text { OS } \\
{[\text { months }]}\end{array}$ & $\begin{array}{l}\text { ORR } \\
{[\%]}\end{array}$ & $\begin{array}{l}\text { 1 and 2-year survival } \\
{[\%]}\end{array}$ \\
\hline \multirow{2}{*}{ CLEOPATRA [32] } & placebo/trastuzumab/docetaxel $(\mathrm{n}=406)$ & 12.4 & - & 69.3 & - \\
\cline { 2 - 7 } & pertuzumab/trastuzumab/docetaxel $(\mathrm{n}=402)$ & 18.5 & - & 80.2 & - \\
\hline \multirow{2}{*}{ EMILIA [33] } & ado-trastuzumab emtansinse $(\mathrm{n}=495)$ & 9.4 & 30.9 & 43.6 & 85.2 vs. 64.7 \\
\cline { 2 - 7 } & lapatynib + capacitabina $(\mathrm{n}=496)$ & 5.6 & 25.1 & 30.8 & 78.4 vs. 51.8 \\
\hline
\end{tabular}

HER2 inhibitors have shown effectiveness in breast cancer patients with amplification of HER2 gene or high expression of HER2 protein. A multidrug pattern based on petruzumab tested in CLEOPARA research indicated prolongation both PFS and OS time in FISH+ breast cancer patients with metastatic tumors. On the other hand, the EMILIA study also indicated the prolongation of PFS and OS time after treatment with trastuzumab emtansine (T-DM1) in primary breast cancer patients after acquired resistance to trastuzumab and taxanes. 
Until now, it has been proven that standard chemotherapy prolongs survival in gastric cancer patients for 8-10 months. Furthermore, the use of targeted drugs that inhibit abnormal signaling HER2 pathways provides an opportunity to individualize treatment and to obtain more effective therapy results. The ToGA (trastuzumab for gastric cancer) randomized trial demonstrated a higher response rate (13-8 months) in a group of advanced gastric cancer patients with HER2-positive that received trastuzumab in combination with chemotherapy vs. chemotherapy alone (11-1 months). Other studies confirm that the combination of trastuzumab or pertuzumab with standard chemotherapy prolongs PFS and OS in HER2-positive patients [36-39].

The mechanism of resistance to trastuzumab is still unknown. It may be caused by the coexistence of mutations or the amplification of different genes (MUC4, HGF, c-MET, EGFR and IGF-1) and it gives the possibility to attain a stable disease (SD) by using other inhibitors (crizotinib, foretinib). SWOG S413 study showed the effectiveness of lapatinib in a combination of chemotherapy in metastatic breast cancer. Moreover, it has been reported that dacomitinib - pan-HER inhibitor can be used in the effective treatment of gastric cancer. Till now, it has not been strictly defined which method of HER2 disorder determination should be carried out in the correct qualification of patients for trastuzumab therapy [34, 36-39].

Hoffman et al. had found $93.5 \%$ concordance between IHC and FISH positive results in 168 patients. On the other hand, Grin et al. had also observed HER2 gene amplification detected by the FISH technique in $71 \%$ of patients with high HER2 receptor expression (IHC3+). Scarcely 10-20\% of patients with low HER2 expression $(\mathrm{IHC} 1+/ 2+)$ also had positive FISH outcomes. Furthermore, the authors demonstrate $98 \%$ compatibility $(\mathrm{p}=0.001)$ between FISH and DISH results in 50 patients with gastric cancer and oesophagus adenocarcinoma. The concordance between IHC and ISH results was summarized in Table $3[34,40]$.

Lee et al. had found ROS1 gene rearrangement in $4 \%$ of gastric cancer patients (23/495) with high positive IHC outcomes (3+). Only 3 of them were FISH positive, whereas positive RT-PCR results in 2 patients were observed. Although no differences in OS between patients with ROS1 gene rearrangement and without this rearrangement were shown, ROS1 gene analysis is recommended. Moreover, the coexistence of abnormalities in ROS1 and $c$-MET signaling pathways were also determined. Therefore, these disorders may be important in future planning of molecularly-targeted therapies [41].

\section{The Significance of FISH Analysis in Qualifications for Anti-EGFR Targeted Therapy in Colorectal Cancer}

Previous studies in colorectal cancer have shown that the sensitivity of monoclonal antibodies (cetuximab, panitumumab) is determined by the activation of different signal pathways: EGFR-RAS-RAF-MAPK or EGFR-PI3K-PTEN-AKT. It has also been observed that the EGFR expression does not correlate with the efficiency of anti-EGFR therapy. A response to cetuximab is observed in patients with overexpression or low expression of the EGFR receptor and with the wild-type of KRAS, NRAS and BRAF genes, whereas cetuximab shows a significantly higher response rate in patients with increased EGFR GCN [6, 7, 9, 42].

Table 3. Summary of HER2 status analysis by IHC and FISH/DISH

\begin{tabular}{|l|l|l|l|l|c|}
\hline \multirow{5}{*}{ Hoffman et al. [40] } & & IHC3+ & IHC2+ & IHC1+ & IHC0 \\
\cline { 2 - 6 } & FISH+ $(\mathrm{n}=30)$ & 18 & 5 & 2 & 4 \\
\cline { 2 - 6 } & FISH- $(\mathrm{n}=140)$ & 0 & 9 & 22 & 109 \\
\hline \multirow{5}{*}{ Grin et al. [36] } & FISH+ $(\mathrm{n}=6)$ & 5 & 1 & 0 & 0 \\
\cline { 2 - 6 } & FISH- $(\mathrm{n}=44)$ & 2 & 9 & 12 & 21 \\
\cline { 2 - 6 } & DISH+ $(\mathrm{n}=7)$ & 5 & 2 & 0 & 0 \\
\cline { 2 - 6 } & DISH- $(\mathrm{n}=43)$ & 2 & 8 & 12 & 21 \\
\hline
\end{tabular}

Hoffman et al. and Grin et al. analysis had shown a high concordance between IHC and FISH results in gastric cancer patients. The results had coincided especially for IHC3+ and IHC0. The discrepancy in IHC2, IHC1 and FISH results suggests that these results are uncertain and they always require confirmation by the FISH technique. Moreover, Grin et al. had indicated a significant compatibility $(\mathrm{p}=0.001)$ between FISH and DISH results that suggests that both of them can be used as reference method. 
Table 4. Summary of correlation between clinical benefits from anti-EGFR treatment and EGFR GCN detected by the FISH method in colorectal cancer patients [44]

\begin{tabular}{|l|l|l|l|l|l|}
\hline & \multirow{2}{*}{$\begin{array}{l}\text { Disease control } \\
(\mathrm{PR}+\mathrm{SD})\end{array}$} & \multicolumn{2}{|l|}{$\mathbf{1}^{\text {st }}$ line chemotherapy } & \multicolumn{2}{l|}{$3^{\text {rd }}$ line chemotherapy } \\
\cline { 3 - 7 } & & PFS (weeks) & OS (weeks) & PFS (weeks) & OS (weeks) \\
\hline FISH + (high GCN) & $73 \%$ & 35 & 85 & 35 & 74 \\
\hline FISH - (low GCN) & $20 \%$ & 12 & 19 & 10 & 16 \\
\hline
\end{tabular}

Algars et al. had observed a clinical benefit in $73 \%$ of patients with high EGFR GCN. On the other hand, only $20 \%$ of patients with low EGFR GCN responded to therapy. Moreover, a high EGFR GCN in comparison to a low EGFR GCN also was associated with significantly longer PFS $(\mathrm{p}=0.0001)$ and OS $(\mathrm{p}=0.004)$ both in first and more lines of treatment.

Jiang et al., based on the positive FISH results in 39\% (302/776) of patients, had shown an increase in EGFR GCN. It was significantly associated with OS and PFS improvement in patients treated with anti-EGFR monoclonal antibodies. Moreover, it was found that in the treated population with increased EGFR GCN, KRAS gene mutations were not found [7].

Campanella et al. had evaluated the expression of an EGFR receptor in 101 patients. They found 89\% positive IHC results, whereas the EGFR gene amplification (FISH+) was observed in 59\% of them. There was no correlation between the positive IHC and FISH results. The 43/101 patients were qualified for first line treatment (chemotherapy with cetuximab or with placebo), whereas cetuximab monotherapy in second-line was applied to 56 patients. They had observed 12 months PFS (vs. 6 months) and a 70\% response rate (RR) (vs. 18\%) in the first line of treatment containing cetuximab. On the other hand, RR in patients with EGFR gene amplification was $48 \%$ vs. $21 \%$ in negative FISH group received cetuximab. The analysis also showed that overexpression of an EGFR receptor evaluated at $2+/ 3+$ in the IHC technique had a significant impact on PFS prolongation in cetuximab-treated patients [43].

Algars et al. had observed stable disease (SD) or partial response (PR) in $84 \%$ of patients, who had high EGFR GCN (FISH+). Furthermore, anti-EGFR therapy allowed us to prolong PFS in this group for 35 weeks (Table 4). Yang et al. had also reported that the high EGFR GCN had a positive impact on the overall response rate (ORR) in $84 \%$ of treated patients. These studies demonstrate that a thorough analysis of EGFR GCN has indisputable predictive value for molecularly-targeted agents in patients with colorectal cancer $[44,45]$.

\section{Conclusion}

The application of in situ hybridisation methods for the detection of molecular aberrations has a high diagnostic value in the qualification of cancer patients for molecularly-targeted therapies (predictive factors). The availability of different diagnostic techniques allows for the accurate evaluation of patients' genetic status. Unfortunately, inconveniences resulting from the low quality of paraffin-embedded tissue samples significantly reduce the usefulness of ISH techniques, which often do not show sufficient sensitivity. However, the FISH technique is still recommended as a reliable method in the precise determination of chromosomal aberrations. Moreover, FISH assessment provides not only a correct qualification of patients to appropriate treatment regimen but is also essential in the rationalization of treatment costs.

\section{References}

[1] Jemal A, Bray F, Center MM, Ferlay J: Global cancer statistics. CA Cancer J Clin 2011, 61, 69-90.

[2] Planchard D: Identification of driver mutations in lung cancer: first step in personalized cancer. Targ Oncol 2013, 8, 3-14.

[3] Tsao MS, Sakurada A, Cutz JC, Zhu CQ, Kamel-Reid S, Squire J, Lorimer I, Zhang T, Liu N, Daneshmand M, Marrano P, da Cunha Santos G, Lagarde A, Richardson F, Seymour L, Whitehead M, Ding K, Pater J, Shepherd FA: Erlotinib in lung cancer - molecular and clinical predictors of outcome. N Engl J Med 2005, 353,133-144.

[4] Gnad F, Baucom A, Mukhyala K, Manning G, Zhang Z: Assessment of computational methods for predicting the effects of missense mutations in human cancers. BMC Genomics 2013. DOI:10.1186/1471-2164-14-S3-S7.

[5] Vogelstein B, Papadopoulos N, Velculescu VE, Zhou S, Diaz LA, Kinzler KW: Cancer genome landscapes. Science 2013, 29, 1546-1558.

[6] Sartore-Bianchi A, Fieuws S, Veronese S, Moroni M, Personeni N, Frattini M, Torri V, Cappuzzo F, Borght SV, Martin V, Skokan M, Santoro A, Gambacorta M, Tejpar S, Varella-Garcia M, Siena S: Standardisation of EGFR FISH in colorectal cancer: results of an international interlaboratory reproducibility ring study. J Clin Pathol 2012, $65,218-223$. 
[7] Jiang Z, Li C, Li F, Wang X: EGFR gene copy number as a prognostic marker in colorectal cancer patients treated with cetuximab or panitumumab: A systematic review and meta analysis. PLoS ONE 2013, 8, 56205-56212.

[8] Sauter G, Lee J, Bartlett J, Slamon DJ, Press MF: Guidelines for human epidermal growth factor receptor 2 testing: biologic and methodological considerations. J Clin Oncol 2009, 27, 1323-1333.

[9] Han CB, Ma JT, Li F, Zou HW: Molecular markers for the prediction of anti-EGFR monoclonal antibody treatment efficacy in metastatic colorectal cancer. J Cancer Therapy 2011, 2, 675-682.

[10] Cortes J, Fumoleau P, Bianchi GV, Petrella TM, Gelmon K, Pivot X, Verma S, Albanell J, Conte P, Lluch A, Salvagni S, Servent V, Gianni L, Scaltriti M, Ross GA, Dixon J, Szado T, Baselga J: Pertuzumab monotherapy after trastuzumab-based treatment and subsequent reintroduction of trastuzumab: activity and tolerability in patients with advanced human epidermal growth factor receptor 2-positive breast cancer. J Clin Oncol 2012, 30, $1594-1600$.

[11] Thunnissen E, Bubendorf L, Dietel M, Elmberger G, Kerr K, Lopez-Rios F, Moch H, Olszewski W, Pauwels P, Penault-Llorca F, Rossi G: EML4-ALK testing in non-small cell carcinomas of the lung: a review with recommendations. Virchows Arch 2012, 461, 245-257.

[12] Marchetti A, Ardizzoni A, Papotti M, Crinò L, Rossi G, Gridelli C, Barberis M, Maiorano E, Normanno N, Taddei GL, Scagliotti G, Clemente C, Pinto C: Recommendations for the analysis of ALK gene rearrangements in non-small-cell lung cancer. A consensus of the Italian Association of Medical Oncology and the Italian Society of Pathology and Cytopathology. J Thorac Oncol 2013, 8, 352-358.

[13] Sholl LM, Xiao Y, Joshi V, Yeap BY, Cioffredi LA, Jackman DM, Lee C, Jänne PA, Lindeman NI: EGFR mutation is a better predictor of response to tyrosine kinase inhibitors in non-small cell lung carcinoma than FISH, CISH, and immunohistochemistry. Am J Clin Pathol 2010, 133, 922-934.

[14] Furrer D, Jacob S, Caron C, Sanschagrin F, Provencher L, Diorio C: Validation of a new classifier for the automated analysis of the human epidermal growth factor receptor 2 (HER2) gene amplification in breast cancer specimens. Diagn Pathol 2013, 8, 17-26.

[15] Murakami Y, Mitsudomi T, Yatabe YA: A screening method for the ALK fusion gene in NSCLC. Front Oncol 2012. DOI: $10.3389 /$ fonc.2012.00024.

[16] Untch M, Lück HJ: Lapatinib - member of a new generation of ErbB-targeting drugs. Breast Care 2010, 5, 8-12.

[17] Kim ES, Hirsh V, Mok T, Socinski MA, Gervais R, Wu YL, Li LY, Watkins CL, Sellers MV, Lowe ES, Sun Y, Liao ML, Osterlind K, Reck M, Armour AA, Shepherd FA, Lippman SM, Douillard JY: Gefitinib versus docetaxel in previously treated non-small-cell lung cancer (INTEREST): a randomised phase III trial. Lancet 2008, 372, 1809-1818.

[18] Wang F, Fu S, Shao Q, Zhou YB, Zhang X, Zhang X, Xue C, Lin JG, Huang LX, Zhang L, Zhang WM, Shao JY: High EGFR copy number predicts benefits from tyrosine kinase inhibitor treatment for non-small cell lung cancer patients with wild-type EGFR. J Transl Med 2013, 11, 90-100.

[19] Liang Z, Zhang J, Zeng X, Gao J, Wu S, Liui T: Relationship between EGFR expression, copy number and mutation in lung adenocarcinomas. BMC Cancer 2010, 10, 376-385.

[20] Brugger W, Triller N, Blasinska-Morawiec M, Curescu S, Sakalauskas R, Manikhas GM, Mazieres J, Whittom R, Ward C, Mayne K, Trunzer K, Cappuzzo F: Prospective molecular marker analyses of EGFR and KRAS from a randomized, placebo-controlled study of erlotinib maintenance therapy in advanced non-small-cell lung cancer. J Clin Oncol 2011, 29, 4113-4120.

[21] Fukuoka M, Wu YL, Thongprasert S, Sunpaweravong P, Leong SS, Sriuranpong V, Chao TY, Nakagawa K, Chu DT, Saijo N, Duffield EL, Rukazenkov Y, Speake G, Jiang H, Armour AA, To KF, Yang YC, Mok TDK: Biomarker analyses and final overall survival results from a phase III, randomized, open-label, first-line study of gefitinib versus carboplatin/paclitaxel in clinically selected patients with advanced non-small-cell lung cancer in Asia (IPASS). J Clin Oncol 2011, 29, 2866-2874.

[22] Yi ES, Boland JM, Maleszewski JJ, Roden AC, Oliveira AM, Aubry MC, Erickson-Johnson MR, Caron BL, Li Y, Tang H, Stoddard S, Wampfler J, Kulig K, Yang P: Correlation of IHC and FISH for ALK gene rearrangement in non-small cell lung carcinoma. IHC score algorithm for FISH. J Thorac Oncol 2011, 6, 459-465.

[23] Kim H, Yoo SB, Choe JY, Paik JH, Xu X, Nitta H, Zhang W, Grogan TM, Lee CT, Jheon S, Chung JH: Detection of ALK gene rearrangement in non-small cell lung cancer: A comparison of fluorescence in situ hybridization and chromogenic in situ hybridization with correlation of ALK protein expression. J Thorac Oncol 2011, 6, 1359-1366.

[24] Chen TD, Chang IC, Liu HP, Wu YC, Wang CL, Chen YT, Chen YR, Huang SF: Correlation of anaplastic lymphoma kinase overexpression and the EML4-ALK fusion gene in non-small cell lung cancer by immunohistochemical study. Chang Gung Med J 2012, 34, 309-317.

[25] Zhang YG, Jin ML, Li L, Zhao HY, Zeng X, Jiang L, Wei P, Diao XL, Li X, Cao Q, Tian XX: Evaluation of ALK rearrangement in Chinese non-small cell lung cancer using FISH, immunohistochemistry, and real-time quantitative RT-PCR on paraffin-embedded tissues. PLoS One 2013. DOI:10.1371/journal.pone.0064821.

[26] Wu YC, Chang IC, Wang CL, Chen TD, Chen YT, Liu HP, Chu Y, Chiu YT, Wu TH, Chou LH, Chen YR, Huang SF: Comparison of IHC, FISH and RT-PCR methods for detection of ALK rearrangements in 312 nonsmall cell lung cancer patients in Taiwan. PLoS ONE 2013 8: e70839. DOI:10.1371/journal.pone.0070839.

[27] Bergethon K, Shaw AT, Ou SH, Katayama R, Lovly CM, McDonald NT, Massion PP, Siwak-Tapp C, Gonzalez A, Fang R, Mark EJ, Batten JM, Chen H, Wilner KD, Kwak EL, Clark JW, Carbone DP, Ji H, Engelman JA, Mino-Kenudson M, Pao W, Iafrate AJ: ROS1 rearrangements define a unique molecular class of lung cancers. J Clin Oncol 2012, 30, 863-870. 
[28] Davies KD, Le AT, Theodoro MF, Skokan MC, Aisner DL, Berge EM, Terracciano LM, Cappuzzo F, Incarbone M, Roncalli M, Alloisio M, Santoro A, Camidge DR, Varella-Garcia M, Doebele RC: Identifying and targeting ROS1 gene fusions in non-small cell lung cancer. Clin Cancer Res 2012, 18, 4570-4579.

[29] Jacquemier J, Spyratos F, Esterni B, Mozziconacci MJ, Antoine M, Arnould L, Lizard S, Bertheau P, Lehmann-Che J, Fournier CB, Krieger S, Bibeau F, Lamy PJ, Chenard MP, Legrain M, Guinebretière JM, Loussouarn D, Macgrogan G, Hostein I, Mathieu MC, Lacroix L, Valent A, Robin YM, Revillion F, Triki ML, Seaume A, Salomon AV, de Cremoux P, Portefaix G, Xerri L, Vacher S, Bièche I, Penault-Llorca F: SISH/CISH or qPCR as alternative techniques to FISH for determination of HER2 amplification status on breast tumors core needle biopsies: a multicenter experience based on 840 cases. BMC Cancer 2013, 13, 351-363.

[30] Gullo G, Bettio D, Zuradelli M, Masci G, Giordano L, Bareggi C, Tomirotti M, Salvini P, Runza L, La Verde N, Santoro A: Level of HER2/neu amplification in primary tumours and metastases in HER2-positive breast cancer and survival after trastuzumab therapy. The Breast 2013, 22, 190-193.

[31] Drukker CA, Bueno-de-Mesquita JM, Retèl VP, van Harten WH, van Tinteren H, Wesseling J, Roumen RM, Knauer M, van 't Veer LJ, Sonke GS, Rutgers EJ, van de Vijver MJ, Linn SC: A prospective evaluation of a breast cancer prognosis signature in the observational RASTER study. Int J Cancer 2013, 133, 929-936.

[32] Baselga J, Cortés J, Kim SB, Im SA, Hegg R, Im YH, Roman L, Pedrini JL, Pienkowski T, Knott A, Clark E, Benyunes MC, Ross G, Swain SM: Pertuzumab plus trastuzumab plus docetaxel for metastatic breast cancer. N Engl J Med 2012, 366, 109-119.

[33] Verma S, Miles D, Gianni L, Krop IE, Welslau M, Baselga J, Pegram M, Oh DY, Diéras V, Guardino E, Fang L, Lu MW, Olsen S, Blackwell K: Trastuzumab emtansine for HER2-positive advanced breast cancer. N Engl J Med 2012, 367, 1783-1791.

[34] Nahta R: New developments in the treatment of HER2-positive breast cancer. Breast Cancer 2012, 4, 53-64.

[35] Hamberg P, Bos MM, Braun HJ, Stouthard JM, van Deijk GA, Erdkamp FL, van der Stelt-Frissen IN, Bontenbal M, Creemers GJ, Portielje JE, Pruijt JF, Loosveld OJ, Smit WM, Muller EW, Schmitz PI, Seynaeve C, Klijn JG: Randomized phase II study comparing efficacy and safety of combination-therapy trastuzumab and docetaxel vs. sequential therapy of trastuzumab followed by docetaxel alone at progression as first-line chemotherapy in patients with HER2+ metastatic breast cancer: HERTAX trial. Clin Breast Cancer 2011, 11, 103-113.

[36] Grin A, Brezden-Masley C, Bauer S, Streutker CJ: HER2 in situ hybridization in gastric and gastroesophageal adenocarcinoma: Comparison of automated dual ISH to FISH. Appl Immunohistochem Mol Morphol 2013, 21, 561-566.

[37] Luis M, Tavares A, Carvalho LS, Lara-Santos L, Araújo A, de Mello RA: Personalizing therapies for gastric cancer: Molecular mechanisms and novel targeted therapies. World J Gastroenterol 2013, 38, 6383-6397.

[38] Mello RA, Marques AM, Araújo A: HER2 therapies and gastric cancer: A step forward. World J Gastroenterol 2013, 37, 6165-6169.

[39] Bang YJ, Van Cutsem E, Feyereislova A, Chung HC, Shen L, Sawaki A, Lordick F, Ohtsu A, Omuro Y, Satoh T, Aprile G, Kulikov E, Hill J, Lehle M, Rüschoff J, Kang YK: Trastuzumab in combination with chemotherapy versus chemotherapy alone for treatment of HER2-positive advanced gastric or gastro-oesophageal junction cancer (ToGA): a phase 3, open-label, randomised controlled trial. Lancet 2010, 376, 687-697.

[40] Hofmann M, Stoss O, Shi D, Büttner R, van de Vijver M, Kim W, Ochiai A, Rüschoff J, Henkel T: Assessment of a HER2 scoring system for gastric cancer: results from a validation study. Histopathology 2008, 52, 797-805.

[41] Lee J, Lee SE, Kang SJ, Do IG, Lee S, Ha SY, Cho J, Kang WK, Jang J, Ou SH, Kim KM: Identification of ROS1 rearrangement in gastric adenocarcinoma. Cancer 2013, 119, 1627-1635.

[42] Lin JK, Lin AJ, Lin CC, Lan YT, Yang SH, Li AF, Chang SC: The status of EGFR-associated genes could predict the outcome and tumor response of chemo-refractory metastatic colorectal patients using cetuximab and chemotherapy. J Sur Oncol 2011, 104, 661-666.

[43] Campanella C, Mottolese M, Cianciulli A, Torsello A, Merola R, Sperduti I, Melucci E, Conti S, Diodoro MG, Zeuli M, Paoletti G, Cognetti F, Garufi C: Epidermal growth factor receptor gene copy number in 101 advanced colorectal cancer patients treated with chemotherapy plus cetuximab. J Transl Med 2010, 8, 36-44.

[44] Algars A, Lintunen M, Carpen O, Ristamäki R, Sundström J: EGFR gene copy number assessment from areas with highest EGFR expression predicts response to anti-EGFR therapy in colorectal cancer. Br J Cancer 2011, 105, $255-262$.

[45] Yang AY, Shen WX, Hu XF, Zheng DY, Wu XY, Huang YF, Chen JZ, Mao C, Tang JL: EGFR gene copy number as a predictive biomarker for the treatment of metastatic colorectal cancer with anti-EGFR monoclonal antibodies: a meta-analysis. J Hematol Oncol 2012, 5, 52-61.

\section{Address for correspondence:}

Marcin Nicoś

Department of Pneumonology, Oncology and Allergology

Medical University of Lublin

Jaczewskiego 8

Conflict of interest: None declared

20-954 Lublin

Poland

Tel.: +48 817244293

E-mail: marcin_nicos@interia.pl

Received: 10.03.2014

Revised: 22.04.2014

Accepted: 23.09.2014 